\title{
Students from Portuguese Speaking African Countries in Portuguese Higher Education
}

\section{Joyce Aguiar ${ }^{1}$, Cristina Sin $^{2}$}

${ }^{1}$ Centre for Research in Higher Education Policies, Portugal, ${ }^{2}$ Agency for Assessment and Accreditation of Higher Education, A3ES, Portugal.

\begin{abstract}
Recently, African countries have been making efforts to expand their higher education systems. However, neither capacity nor quality have kept pace with demand, leading to a steady increase in students studying abroad. In this paper, we aim to analyse the development of enrolments in Portugal, one of the main destinations for students from Portuguese-speaking African countries (PALOP). Descriptive analyses were performed, disaggregating enrolments according to degree level, disciplinary area of study, and institution type. The results show that the choices of students from PALOP countries have followed different trajectories, in some cases with similarities. The public sector has the largest presence of these students, and polytechnic institutions have been the most frequent choice. Most of the students were enrolled in first degrees, except for those from Mozambique. Enrolments in Health, Services and "hard" sciences have increased, which may reflect the growing demand for highly qualified labour force in these countries. This paper highlights the continued importance of PALOP students for the internationalisation of Portuguese higher education and the need to avoid considering them as a homogeneous group of students.
\end{abstract}

Keywords: International students; Portuguese speaking African countries; student mobility. 


\section{Introduction}

Africa is the world region that has the highest share of outbound student mobility for tertiary education. Many factors have driven the mobility of African students. First, there is a large university-age population, as $60 \%$ of Africans are under 25 years old and the levels of secondary education completion have been rising (Krtiz, 2015). Second, there is a shift from the agriculture-based system to a manufacturing and service-based system, which implies a demand for more qualified jobs (Langa, 2014). Even with the efforts to expand the higher education (HE) sector, both public and private, the current number of higher education institutions (HEIs) cannot support demand across the continent, leading to a steady increase in students studying abroad. According to UNESCO Institute of Statistics (UIS, 2021), in 2017 African students have become the most mobile tertiary students globally, representing an opportunity for countries and institutions which are keen to diversify their student body. This is China's case, which has made a concerted effort to attract African students, both for undergraduate programmes and for short-term technical programmes. In 2018, they represented $16 \%$ of all international students in China (Mulvey, 2020).

Since 1975, Portugal has received students from Portuguese speaking countries in Africa (PALOP), being the main destination of these countries due to strong historical and linguistic ties. Studies on PALOP students in Portugal have focused on their academic success (Wilks \& Neto, 2019) or social adaptation (França e Cairns, 2020). Nevertheless, there is a lack of literature about the choices which students from different PALOP countries make within the Portuguese HE system. As they represent a large percentage of all degree mobile international students, the continued ability to attract these students is fundamental for Portuguese HEIs, not only from an economic rationale but also from an academic, politic and cultural one (Sin, Antonowicz, \& Wiers-Jenssen, 2019). Knowledge of these students' choices regarding institution type, discipline and degree level can be important to sustain growth in enrolments. The current paper is an exploratory study on PALOP students' enrolments in the Portuguese HE system during the last decade, analysing the data according to each of the five countries, namely Angola, Cape Verde, Guinea Bissau, Mozambique and São Tomé and Principe.

It is only in the last decade that the Portuguese government has taken measures to promote internationalisation actively and to attract international students. Two pieces were paramount to achieve this: the internationalization strategy of Portuguese HE and the Statute of the International Student. With regard to Portugal and its former colonies, Veiga et al. (2006) pointed out that this relationship was based on political and cultural rationalities. Portuguese HEIs have clearly assumed the idea of a "Lusophone space", and cooperation with these countries represents a strategy that strongly reinforces the internationalization of Portuguese HEI. Indeed, the Statute maintains a special regime for students from the PALOP countries, offering scholarships in order to preserve the privileged relationship with these countries (Sin, Tavares \& Cardoso, 2019). Recently, Angola and Cape Verde have represented key 
players for the Portuguese HE system, being respectively the second and third most frequent countries of origin of students in full-degree mobility (DGEEC, 2021).

During the colonial era, Portugal failed to establish HEIs in its former colonies, unlike other European colonial powers, such as the United Kingdom and France. It is important to note that, before the 1960s, when the pressure for independence became increasingly strong, there was no HEI in Portugal's overseas territories (Langa, 2018). In 1962, the first HEIs were established in PALOP countries, namely in Angola and Mozambique. Although the Portuguese government addressed the integration of the African colonized population into the Portuguese way of life, the places were offered primarily to the sons of Portuguese colonialists, while very few Africans managed to reach university level (Langa 2014; 2018).

Except for Angola and Mozambique, HE is a very recent phenomenon in the PALOP countries. Most of its characteristics are similar to the Portuguese system, with some variations developed after independence in the mid-1970s. Besides a historical connection, these students' enrolment in HE in Portugal results from other specific reasons. Having a network of friends and family who live (or have lived) in Portugal can be very important in determining where to study, which can attract more students to Portugal than to other European countries with which they do not share a common past (Ploner \& Nada, 2020).

Also, common language plays a key role in choosing the country destination. As demonstrated in the previous literature, students with proficiency in the host country's language have a better experience (Sin \& Tavares, 2019; Wilks \& Neto, 2016). However, the issue of language deserves more attention. Some researchers have reported language as critical to PALOP students' integration in the host country (França \& Cairns, 2020; Vilela, 2002). On the one hand, HEIs expect that students have fluency in Portuguese, both written and spoken. On the other hand, Portuguese is not their first language, although it is the official one. This may negatively impact their self-efficacy, affecting their academic success and even their social integration into the host society (Sin \& Tavares, 2019; Wilks \& Neto, 2016).

\section{Method and Results}

Data was retrieved from the General Directorate for Education and Science Statistics website, specifically information from the academic year of 2011/12 to 2019/20 on students of all nationalities enrolled in Portuguese HEIs. The dataset is available online in the public domain. For this study, we only considered as countries of origin the five PALOP, namely Angola, Cape Verde, São Tomé and Príncipe (STP), Mozambique and Guinea-Bissau. Descriptive analyses were carried out for each country, disaggregating enrolments according to degree level, disciplinary area of study, and type of HEI. Table 1 shows the evolution of the number of enrolments in Portuguese HEIs by country over the years. 
Table 1. Number of international students from PALOP countries enrolled in Portuguese higher education.

\begin{tabular}{cccccc}
\hline Year & Angola & Cape Verde & Guinea-Bissau & Mozambique & $\begin{array}{c}\text { São Tomé and } \\
\text { Principe }\end{array}$ \\
\hline $2011 / 12$ & 3500 & 3318 & 461 & 674 & 823 \\
$2012 / 13$ & 3314 & 3009 & 420 & 642 & 826 \\
$2013 / 14$ & 3737 & 2740 & 429 & 673 & 811 \\
$2014 / 15$ & 3719 & 2561 & 420 & 731 & 751 \\
$2015 / 16$ & 3741 & 2653 & 543 & 767 & 877 \\
$2016 / 17$ & 3707 & 2781 & 602 & 838 & 1049 \\
$2017 / 18$ & 3969 & 2942 & 838 & 952 & 1267 \\
$2018 / 19$ & 4028 & 3598 & 1722 & 1013 & 1215 \\
$2019 / 20$ & 4299 & 4929 & 3705 & 1257 & 1220 \\
\hline
\end{tabular}

Source: DGEEC (2021).

\subsection{Angola}

Throughout the analysed times series, enrolments of Angolan students grew by $22.82 \%$, as shown in Table 1. There is a preference for the public sector (54.77\%). Nevertheless, a yearby-year analysis reveals that it has not always been so. At the beginning of the period, the distribution of enrolments between public and private was quite balanced $(50.14 \%$ and $49.86 \%$, respectively). In the year $2014 / 15$, the number of enrolments in the public sector overtook private enrolments, reaching $55.42 \%$ in $2019 / 20$.

University education is most prominent $(77.79 \%)$. However, interest for polytechnic education, mainly public, has been growing, from $9.91 \%$ (344) to $17.79 \%$ (757). More than half of the students $(55.39 \%)$ were enrolled in $1^{\text {st }}$ cycle degree courses. Regarding the disciplinary area, just over half $(51.93 \%)$ of students were enrolled in courses belonging to the Social Sciences, Business and Law. Although this is still the most important area, there has been a slight reduction in recent years. Conversely, enrolments in Engineering have increased, from $13.09 \%$ (458) students to $23.68 \%$ (1018) in the analysed period.

\subsection{Cabo Verde}

Comparing the beginning and end of the time series, there is a growth of 48.55 in the enrolments of Cape Verdean students (see Table 1). There is a preference for public education $(82.83 \%)$, and a year-by-year analysis shows that this preference has intensified over the 
period. In $2011 / 12,75.91 \%$ of students were enrolled in public institutions, increasing to $83,47 \%$ in $2019 / 20$.

The division between university (50.04\%) and polytechnic enrolments is quite balanced. Nevertheless, while university education was predominant $(66.15 \%)$ at the beginning of the period, over time this difference decreased. From 2016/17, polytechnic institutions started to have more enrolments. In 2019/20, 64.5\% of students were in polytechnic education. Such growth is mainly due to the rapid growth in enrolments in the public polytechnic subsector, which went from $31.83 \%$ (1053) to $55.01 \%$ (2699).

The majority (64.24\%) of students are enrolled in the $1^{\text {st }}$ cycle. The growth in CTeSP (short technical courses) enrolments is noteworthy, from 3.23\% (107) to $13.02 \%$ (639). Concerning the disciplinary area, the most chosen courses are those belonging to the Social Sciences, Business and Law (36.47\%) and Engineering (26.03\%). Although Health is in third place, its growth is worth highlighting, from $6.39 \%$ (230) to $14.40 \%$ (710).

\subsection{Guinea Bissau}

Among the PALOP countries, Guinea-Bissau is the one that shows the highest proportional growth of enrolments in Portuguese HEI, registering eight times more students in 2019/20 than in 2011/12, as shown in Table 1.

Enrolments in public institutions are by far dominant (82.94\%). Regarding the type of education, the preference for polytechnic education grew from $26.52 \%$ (122) to $64.15 \%$ (2376), making the division between university and polytechnics sectors balanced over the entire time series. The growth in polytechnic education occurred proportionally, both in the public and private sectors. However, in absolute numbers, the public polytechnic is much more prominent, having grown almost 20 times more, from 106 to 2116 .

The majority (66.07\%) of students are in 1st cycle degree courses. The growth in CTeSP courses is noteworthy, from zero to $1389(15.26 \%)$. Regarding the disciplinary area, just over half $(54.68 \%)$ are in Social Sciences, Business and Law. Concerning the other disciplinary areas, it is observed that the ones with the highest growth were Services (from $3.38 \%$ to 9.13\%) and Natural Science, Mathematics and Informatics (from $2.60 \%$ to $7.46 \%$ )

\subsection{Mozambique}

An increase of $86.49 \%$ was observed in the enrolments of Mozambican students. There is a clear preference for the public sector $(87.05 \%)$, which has intensified over the period, in parallel with a reduction in the private sector, from $19.94 \%$ to $7.92 \%$. University education predominates (83.75\%), making Mozambique the only analysed country in which the public polytechnic sub-sector is not the one experiencing the highest growth. 
Although, as in all PALOP countries, $1^{\text {st }}$ cycle degrees register the highest number of enrolments, there is a greater distribution among the other degrees. Namely, $36.26 \%$ of students are in master degrees $(21.98 \%$ in 2 nd cycle master degrees and $14.28 \%$ in integrated masters) and $25.29 \%$ in doctorates. In this case, it is the public university sub-sector that registers the greatest growth, having in 2019/20 doubled the number of students compared to 2011/12. Most students are in Social Sciences (41.62\%) and Engineering (16\%). The growth in the areas of Health is noteworthy, from $6.97 \%$ to $12.65 \%$.

\subsection{São Tomé and Principe (STP)}

Enrolments of students from STP went from 823 to 1220 , representing an increase of $48.23 \%$. As in the other PALOP countries, there is a preference for public education $(82.83 \%)$. The growth of the public polytechnic subsector was more accentuated, while the remaining subsectors experienced a reduction. This happened mainly more recently and, in the last year, about $69 \%$ of students were enrolled in polytechnic education. Analysing the entire historical series, it is observed that $55.37 \%$ of the students from STP are in polytechnic education.

Most students are enrolled in $1^{\text {st }}$ cycles $(65.24 \%)$. It is important to note that the number of enrolments in CTeSP throughout the historical series has almost quintupled, from 26 to 123 , with most of these students in public polytechnic schools.

Almost half of the students from the entire period study Social Sciences, Business and Law $(51.27 \%)$. The growth in Natural Sciences, Mathematics and Informatics stands out $(1.46 \%$ to $8.45 \%$ ).

\section{Discussion and Conclusion}

The current study has analysed the last decade of enrolments of PALOP students, contributing to a more nuanced overview of how the internationalisation of the Portuguese HE system has been marked by the choices and distribution patterns of these students.

Angolan students are the most represented ones in this group of countries, followed by Cape Verdean students. The latter have grown very rapidly in recent years, mainly enrolling in polytechnic education. Considering proportional growth, however, Guinea-Bissau is the country that presents the biggest increase in the number of enrolments.

The results show changes over the past few years, allowing a better understanding of which segments are most preferred by students, according to their nationality. Some aspects are shared among the five countries, for example, the predominance of public rather than private institutions, which can probably be explained by the special regime for granting scholarships to students from PALOP. However, for some countries, the choice of the public sector is more marked, as is the case of Mozambique. In fact, this country distinguishes itself from the 
rest of the PALOP countries in an additional way: most Mozambican students are enrolled in more advanced degrees (i.e. master and $3^{\text {rd }}$ cycle), contrasting with the $1^{\text {st }}$ cycle and CTeSP, which is dominant for the other African students.

With regard to the type of education, Angolan and Mozambican students are strongly present in university education, while students from STP are in polytechnic education. However, there has been a change in recent years: enrolments of Cape Verdean and Guinean students have grown rapidly in polytechnics institutions, especially in the public sector. In fact, public polytechnics is the fastest growing subsector, except for students from Mozambique.

Health, Services, Engineering and Natural Sciences, Mathematics and Informatics stand out among the disciplinary areas with the highest growth, although Social Sciences, Business and Law continue to dominate. Considering that polytechnic education is more oriented towards practical training and the labour market, the greater demand in these courses and in this type of institution may be related to the transition that PALOP countries have experienced in terms of economic sectors. With the transition to a manufacturing economy, high-skilled jobs in areas such as agricultural engineering, telecommunications and civil engineering are on the rise, as are jobs related to health and tourism. This suggests that HEIs with educational offerings in these areas could look at Africa as a promising source of potential candidates.

Finally, some limitations must be noted. As international students, we considered those who are not born in the country where they study, given the data limitations. Although they are counted in national data as degree-mobile students, they can be long-term residents or may have even acquired dual nationality.

HE is a rather recent development in PALOP countries and demand for HE is growing fast. The African continent is the second-largest in the world, and it is unwise to consider the entire continent as a homogeneous group, without attention to the specificities of each country or group of countries. In fact, an imaginary form of an African student is actually a stereotype that reverberates neo-racism, by disregarding the social, ethnic or national origin of the students (França \& Cairns, 2020). This work is expected to open new avenues for understanding the PALOP students' distinctive preferences within Portuguese HE. As Portugal is not a major recruiter of international students, but is the main destination for those coming from PALOP countries, maintaining attractiveness for these students is essential for the successful internationalisation of Portuguese HEI's student body.

\section{References}

DGEEC (2021). Estatísticas - Inscritos em estabelecimentos de ensino superior - 2011/12 a 2019/20 [Statistics - Enrolled in higher education institutions - from 2011/12 to 2019/10I]. Accessed February, 2021 
França, T. \& Cairns, D. (2020) South-South student migration: socially integrating students from Portuguese-speaking Africa at UNILAB, Brazil. Globalisation, Societies and Education, 18(5), 578-588. doi: 10.1080/14767724.2020.1805301

Kritz, M. M. (2015). International student mobility and tertiary education capacity in Africa. International Migration, 53(1), 29-49. doi: 10.1111/imig.12053

Langa, P. V. (2018). Higher education as a field of research in the Portuguese-speaking countries: Insights on an emerging scientific field. International Journal of African Higher Education, 4(2). doi: 10.6017/ijahe.v4i2.10296

Langa, P. V. (2014). Higher education in Portuguese-speaking African countries. African Minds.

Mulvey, B. (2020). International higher education and public diplomacy: A case study of Ugandan graduates from Chinese universities. Higher Education Policy 33, 459-477. doi: $10.1057 / \mathrm{s} 41307-019-00174-\mathrm{w}$

Ploner, J., \& Nada, C. (2020). International student migration and the postcolonial heritage of European higher education: Perspectives from Portugal and the UK. Higher Education 80, 373-389. doi: 10.1007/s10734-019-00485-2

Sin, C., Antonowicz, D., \& Wiers-Jenssen, J. (2019). Attracting international students to semi-peripheral countries: A comparative study of Norway, Poland and Portugal. Higher Education Policy. doi:10.1057/s41307-019-00135-3.

Sin, C., Tavares, O., \& Cardoso, S. (2019). Portuguese Institutions' Strategies and Challenges to Attract International Students: External Makeover or Internal Transformation? Journal of International Students, 9(4), 1095-1114. doi: 10.32674/jis.v9i4.185

UNESCO Institute for Statistics (2021). Retrieved from http://uis.unesco.org/en/uis-studentflow, accessed February 2021.

Veiga, A., Rosa, M., \& Amaral, A. (2006). The internationalisation of Portuguese higher education: How are higher education institutions facing this challenge? Higher Education Management, 18(1), 113-28.

Vilela, M. (2002) Reflections on language policy in African countries with Portuguese as an official language. Current Issues in Language Planning, 3(3), 306-316. doi: 10.1080/14664200208668043

Wilks, D. C., \& Neto, F. (2016). Exploring the adaptation experiences of Cape Verdean students in Portugal. International Journal of Educational Research, 76, 66-75. doi: 10.1016/j.ijer.2016.01.002 